\title{
36. SURVEY OF DIATOMS IN THE UPPER OLIGOCENE AND LOWER MIOCENE IN HOLES 515B AND 516 ${ }^{1}$
}

\author{
Andrew M. Gombos, Jr., Exxon Production Research Company, Houston, Texas
}

\begin{abstract}
Samples from the upper Oligocene and lower Miocene of Holes 515B (Brazil Basin) and 516F (Rio Grande Rise) were examined for fossil marine diatom content. The preservation of the diatoms was poor and the species diversity low in both holes. However, it was possible to zone portions of the intervals studied using the zonation proposed by Gombos and Ciesielski (1983), which is based, as far as possible, on common and robust species. Thus, the interval in Hole 515B represented by Cores 515B-15 and 515B-16 is assigned to the Coscinodiscus rhombicus Zone and the interval represented by Cores 515B-17 through 515B-44 is assigned to the Rocella gelida Zone. The C. rhombicus Zone is early Miocene in age and the $R$. gelida Zone is late Oligocene to early Miocene in age. In Hole $516 \mathrm{~F}$ the interval represented by Cores $516 \mathrm{~F}-6$ through $516 \mathrm{~F}-10$ is assigned to the $R$. gelida Zone (late Oligocene to early Miocene), and the interval represented by Cores $516 \mathrm{~F}-11$ through $516 \mathrm{~F}-15$ is assigned to the Triceratium groningensis Zone (late Oligocene). Two new fossil diatom taxa are defined herein: Coscinodiscus lewisianus Greville $\mathrm{f}$. concavus $\mathrm{n}$. $\mathrm{f}$. and Rocella semigelida $\mathrm{n}$. $\mathrm{sp}$.
\end{abstract}

\section{INTRODUCTION}

This report is a summary of the stratigraphic distribution of 39 diatom species in the upper Oligocene to lower Miocene intervals at Holes 515B and 516F, located in the Brazil Basin and on the Rio Grande Rise respectively. Preservation of diatom valves in both holes is very poor, and the diversity of species in each assemblage is low. Portions of the upper Oligocene and lower Miocene sections in Holes $515 \mathrm{~B}$ and $516 \mathrm{~F}$ have been zoned on the basis of diatoms by the zonation proposed by Gombos and Ciesielski (1983) for the upper Oligocene and lower Miocene of the southwestern Atlantic.

\section{HOLE 515B}

\section{Background and Objectives}

Hole 515B is located at $26^{\circ} 14.32^{\prime} \mathrm{S}, 36^{\circ} 30.19^{\prime} \mathrm{W}$ at a water depth of $4252 \mathrm{~m}$ in the southern Brazil Basin about $200 \mathrm{~km}$ north of the northern exit of the Vema Channel. It was cored continuously; a total of 57 cores were taken from 94.9 to $636.4 \mathrm{~m}$ sub-bottom.

Three lithologic units were identified in Hole 515B: Unit I, consisting of terrigenous mud; Unit II, which is subdivided into Unit IIA consisting of siliceous mud and mudstone and Unit IIB consisting of terrigenous mudstone; and Unit III, which is a calcareous zeolitic mudstone. Diatoms occur in the lowest part of Unit I and through most of Unit IIA. Units IIB and III have no diatoms.

The objectives of this investigation were to determine the ages of cored sediments and to detect evidence of current-transported diatoms.

\section{MATERIAL AND METHODS}

For this study, a total of 43 samples were processed and examined according to the procedure outlined by Gombos and Ciesielski (1983).

\footnotetext{
${ }^{1}$ Barker, P. F., Carlson, R. L., Johnson, D. A., et al., Init. Repts. DSDP, 72: Washington (U.S. Govt. Printing Office).
}

These samples represent one sample per core from all but three cores of Cores 515B-8 through 515B-53 (no samples from Core 515-9, $515-24$, or $515-42)$.

\section{Observations}

Diatoms are present in all samples from Cores 515B8 through 515B-44, but absent from Cores 515B-45 through 515B-53. Although diatoms occur consistently in Cores 515B-8 through 515B-44, overall the abundance is low and preservation is poor. A few samples contain common and well-preserved diatoms, but these are exceptional. Figure 1 summarizes the abundance and preservation of diatoms in the samples studied.

Because the abundance of diatoms in most of the samples is very low, usually no more than one to three specimens of any particular species, any estimate of relative abundance is virtually meaningless. For this reason, only the presence or absence of each individual species is given in Figure 1.

\section{Biostratigraphy}

Figure 2 illustrates the lithology of the cored interval in Hole 515B as determined by shipboard scientists. Also illustrated on Figure 2 are age determinations based on calcareous nannofossils and planktonic foraminifers (site chapter, Site 515, this volume). The occurrence of calcareous microfossils in Hole 515B is sporadic, and their preservation is generally poor. For this reason, precise age determinations based on the calcareous microfossils were not possible. The right-hand side of Figure 2 contains the ranges of eight selected diatom species, diatom zones, and age determinations based on diatoms for Hole 515B. The diatom biostratigraphy is further discussed below.

Gombos and Ciesielski (1983) defined 12 diatom biostratigraphic zones for the upper Eocene to lower Miocene sediments in a composite section based on cores from Holes 511 and 513A in the southwest Atlantic Ocean. Two of the zones of Gombos and Ciesielski (1983) were identified in Hole 515B. The Coscinodiscus 


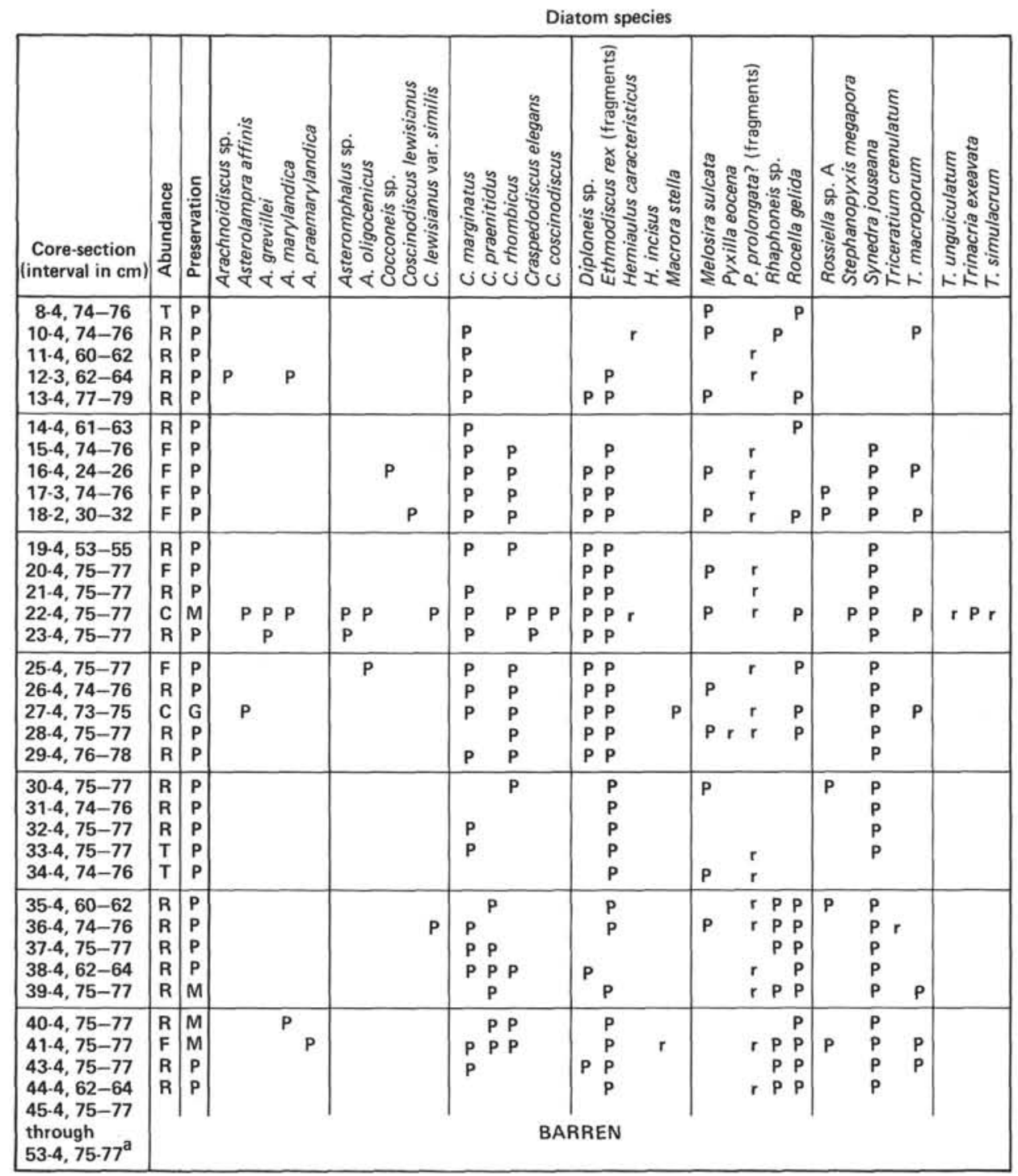

Note: Abundance column: $C=$ common, $F=$ few, $R=$ rare, $T=$ trace;

Preservation column: $\mathrm{G}=$ good, $\mathrm{M}=$ moderate, $\mathrm{P}=$ poor;

Diatom columns: $P=$ present,$r=$ present but suspected reworking, blank $=$ absent.

an Sample $50-4,100-120 \mathrm{~cm}$ there is a trace of pyritized diatoms.

Figure 1. Occurrence, abundance, and preservation of diatoms in samples from Hole 515B.

rhombicus Zone was identified in Cores 515B-15 and 515B-16; the Rocella gelida Zone was identified in Cores 515B-17 through 515B-44.

In the reference section in Hole 513A, the C. rhombicus Zone is early Miocene in age. The $R$. gelida Zone, in the reference section, straddles the Oligocene/Miocene boundary. The Oligocene/Miocene boundary cannot be more precisely defined within the $R$. gelida Zone because there is no significant appearance or extinction datum near the boundary. Gombos and Ciesielski (1983) discuss the use of relative abundance changes of $R$. gelida and Rossiella sp. as secondary tools in the determination of the Oligocene/Miocene boundary. In Hole 513A the boundary occurs just after the acme of Rocella geli$d a$ and just below the lowest abundant occurrence of Rossiella sp. Both of these events occur within the Rocella gelida Zone.
In Hole 515B, no significant abundance change for Rossiella sp. was detected. The maximum abundance of Rocella gelida was observed in Core 515B-36. In the slide from that sample, 12 specimens of $R$. gelida were observed during two traverses at $\times 400$. In samples from cores above Core 515B-36, no more than one specimen of $R$. gelida was ever observed. The maximum abundance of $R$. gelida in Core 515B-36 may represent the acme of that species, though it is a very tenuous determination.

The occurrence of eight selected species at Hole 515B is illustrated in Figure 2. Of these species, $R$. gelida, C. rhombicus, and Rossiella sp. straddle the Oligocene/ Miocene boundary in Hole 513A. The lower range of $C$. lewisianus and $C$. lewisianus var. similis is not known. Craspedodiscus elegans occurs in the lower Miocene of the western North Atlantic (Gombos, unpublished data). 


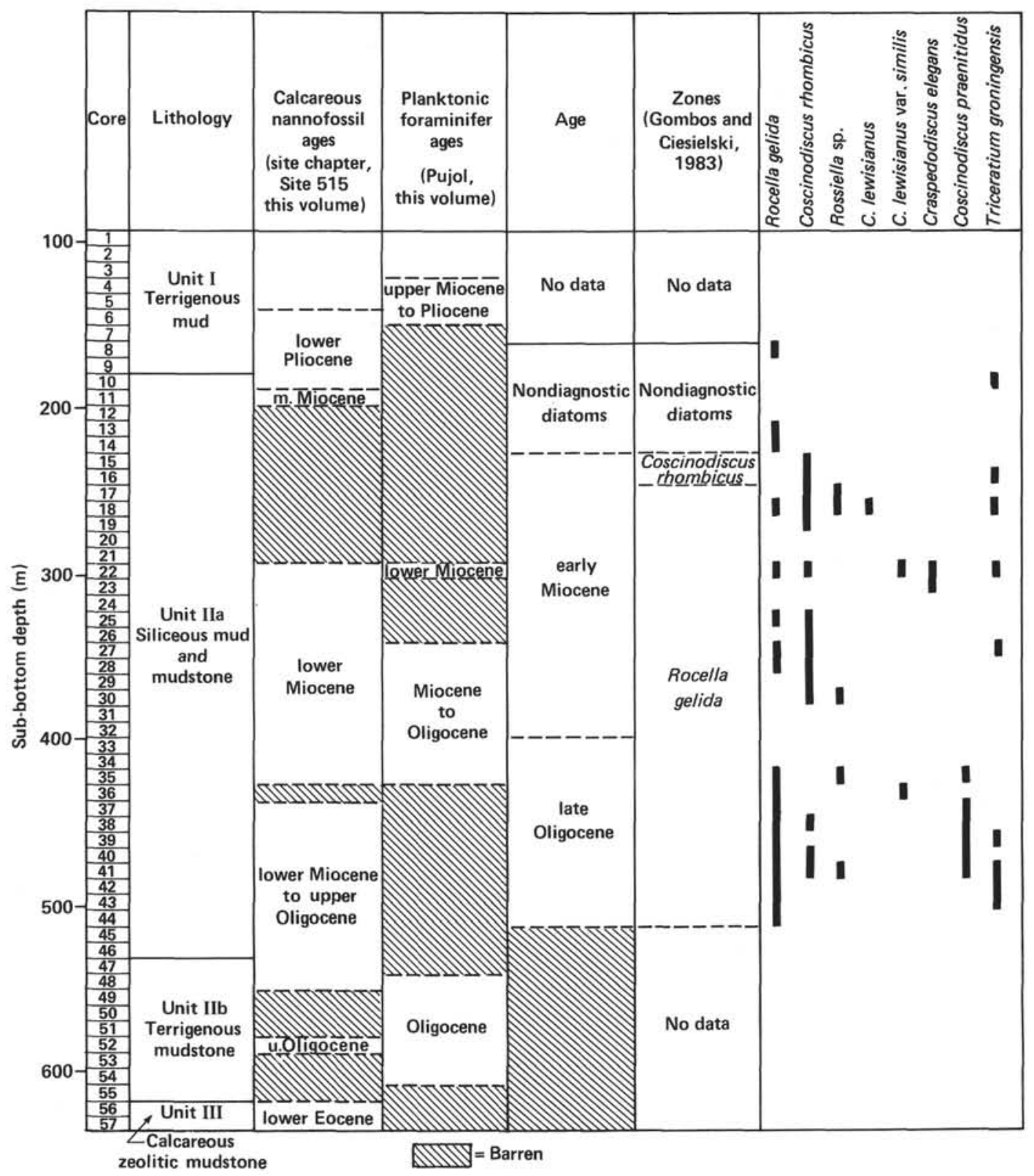

Figure 2. Lithology, calcareous microfossil ages and diatom zones, ages, and selected diatom species occurrence in Hole 515B.

Coscinodiscus praenitidus ranges slightly into the lower Miocene in Hole 513A.

Based on the occurrence of Craspedodiscus elegans and Coscinodiscus praenitidus in Hole 515B, the Oligocene/Miocene boundary should fall between Cores 515B23 and 515B-35. Furthermore, the apparent acme of $R O-$ cella gelida in Core 515B-36 suggests the placement of the boundary higher in the section. For this report, the Oligocene/Miocene boundary is tentatively placed between Cores 515B-32 and 515B-33, in agreement with the diatom data discussed above and also in fairly close agreement with ages determined by calcareous microfossils.

\section{Reworked Diatoms}

In Figure 1, the presence of reworked older species is indicated by "r". Reworked species observed in Hole
515B include Hemiaulus caracteristicus and $H$. incisus, which were found only in the lower Oligocene of Hole 513A (Gombos and Ciesielski, 1983); Pyrgupyxis eoce$n a$ and Pyxilla prolongata, which do not occur below the lower Oligocene (Gombos and Ciesielski, 1983; Jousé, 1979); Trinacria simulacrum, which was observed only in the lower Oligocene and upper Eocene of Hole 511 (Gombos and Ciesielski, 1983); and Triceratum unguiculatum, which is common only in the lower Oligocene of Hole 511.

\section{HOLE 516F}

\section{Background and Objectives}

Site 516 is located at $30^{\circ} 16.59^{\prime} \mathrm{S}, 35^{\circ} 17.11^{\prime} \mathrm{W}$ at a water depth of $1313 \mathrm{~m}$ on the Rio Grande Rise. Hole $516 \mathrm{~F}$ was washed to a depth of $169.1 \mathrm{~m}$ sub-bottom and 
thence continuously cored to a depth of $1270 \mathrm{~m}$ sub-bottom; 128 cores were taken in this interval.

This report deals only with Cores $516 \mathrm{~F}-1$ through $516 \mathrm{~F}-18$ (169.1-340.1 m sub-bottom). The lithology of the interval from Cores $516 \mathrm{~F}-1$ through $516 \mathrm{~F}-18$ consists of nannofossil and nannofossil-foraminifer chalks. It is in this interval that diatoms occur.

The objectives of this study were to determine the stratigraphic distribution of diatoms in the interval from upper Oligocene to lower Miocene; to corroborate the age determinations derived from calcareous microfossil analysis; and to determine if any diatoms were deposited at the site via current transport.

\section{MATERIAL AND METHODS}

A total of 61 samples were processed and examined from Cores $516 \mathrm{~F}-1$ through $516 \mathrm{~F}-18$, according to the method outlined in Gombos and Ciesielski (1983). Figure 3 illustrates the distribution and relative tive abundance of species in each sample. Relative abundances are based on actual counts of specimens observed in two traverses of the cover slip at $\times 400$.

\section{OBSERVATIONS}

Only rare and sporadic diatoms were observed in Cores 516F-1 through 516F-5 (Fig. 3). The diatoms observed in that interval are robust, dissolution-resistant, nondiagnostic forms that are commonly found in very poorly preserved assemblages. In Cores $516 \mathrm{~F}-6$ through $516 \mathrm{~F}-17$ the diatoms are consistent in occurrence and poor to moderately well preserved; the assemblage is moderately diverse ( 36 species were recorded from that interval).

Figure 4 illustrates the occurrences of 11 selected diatom species in Hole $516 \mathrm{~F}$. Only five of these species (Rocella gelida, R. schraderi, $R$. vigilans, Synedra jouseana, and Biddulphia sp.) are distributed continuously in the hole. The continuous distribution of these species is due to their heavily silicified valves, which makes them less susceptible to dissolution than less heavily silicified forms. The other six selected species (Coscinodiscus lewisianus, C. lewisianus var. similis, C. rhombicus, Asterolampra marylandica, Triceratium groningensis, and Lizitziana ornata) are not distributed continuously in Hole $516 \mathrm{~F}$. These forms are apparently less dissolution-resistant than the others, and their sporadic distribution is attributed to the vagaries of preservation.

\section{Biostratigraphy}

Calcareous nannofossil zones identified in Hole $516 \mathrm{~F}$ are illustrated on the left side of Figure 4. These indicate that the Oligocene/Miocene boundary occurs in Core $516 \mathrm{~F}-9$.

Two diatom zones of Gombos and Ciesielski (in press) have been identified in Hole 516F. The upper Oligocene Triceratium groningensis Zone is identified in Cores $516 \mathrm{~F}-11$ through $516 \mathrm{~F}-15$. The $R$. gelida Zone, which straddles the Oligocene/Miocene boundary in the reference section (Hole 513A), is identified in Cores 516F-6 through $516 \mathrm{~F}-10$. The acme of $R$. gelida (see discussion of Hole 515B above) occurs in Core 516F-8. The samples in which the greatest numbers of $R$. gelida were observed, however, correspond to intervals of moderate to good preservation, as indicated by occurrence in those samples of many of the less-resistant species (Fig. 4). On the other hand, the consistency of the occurrence of the species throughout its range suggests that this is a real acme, not an artifact of preservation, particularly given that all samples and slides were prepared and examined in the same manner. If the acme is real, and if the Oligocene/Miocene boundary occurs above the acme of $R$. gelida in Hole $516 \mathrm{~F}$ as it does in the southwestern Atlantic (Gombos and Ciesielski, 1983), then the boundary in Hole $516 \mathrm{~F}$ could occur as high as Core $516 \mathrm{~F}-7$, higher than nannofossil stratigraphy would suggest.

\section{Reworked Diatoms}

No obvious evidence of reworking of older diatoms into the upper Oligocene and lower Miocene sediments of Hole $516 \mathrm{~F}$ was noted. This is in contrast with Hole $515 \mathrm{~B}$, in which lower Oligocene and Eocene diatoms were deposited by bottom currents during the late Oligocene and early Miocene. The position of Hole $516 \mathrm{~F}$ is high on the Rio Grande Rise and thus was not affected by any bottom current activity that was directly related to the flow through the Vema Channel. The diatom assemblage observed in sediment from Hole $516 \mathrm{~F}$ is assumed to represent the planktonic assemblage that existed over the site during late Oligocene and early Miocene. Rare occurrences of benthic diatoms such as Biddulphia, Cocconeis, and Diploneis in Hole 516F (Fig. 3) represent either in situ bottom flora or tychopelagic transport from nearby shelf areas.

\section{TAXONOMIC NOTES AND DESCRIPTIONS OF NEW SPECIES}

Species identified in this study are listed in Table 1. Additional references and synonomies for many of the species can be found in Van Landingham (1967-1979). Illustrations of many of the species can be found in Schmidt (1874-1959), Gombos (1977), Hajós (1976), Fenner (1978), and Gombos and Ciesielski (1983).

The species illustrated herein include the most commonly encountered forms in samples from Holes 515B and 516F. For the most part, these species are robust, dissolution-resistant forms that can be expected to be preserved in otherwise poorly preserved diatomaceous assemblages.

Coscinodiscus lewisianus Greville f. concavus n.f. (Plate 3, Fig. 8)

Description. Valves planar, rhombic, with concave sides; angles rounded; areolae arranged in subparallel, radial rows as in the species; areolae more closely arranged approaching the margin; five areolae in $10 \mu \mathrm{m}$ in longest rows. Long axis of holotype $100 \mu \mathrm{m}$; short axis of holotype $79 \mu \mathrm{m}$.

Holotype. Author's slide D292BJ3; holotype is circumscribed on slide and is illustrated on Plate 3, Figure 8.

Repository. (CM 34390) Section of Invertebrate Fossils, Carnegie Museum of Natural History, 4400 Forbes Avenue, Pittsburgh, Pennsylvania 15213.

Type locality. DSDP Site $516\left(30^{\circ} 16.59^{\prime} \mathrm{S} ; 35^{\circ} 17.11^{\prime} \mathrm{W}\right)$ on the Rio Grande Rise in the South Atlantic Ocean.

Type stratum. DSDP Sample $516 \mathrm{~F}-15-6,80-82 \mathrm{~cm}$ (or 311.90 to $311.92 \mathrm{~m}$ below the sediment surface).

Age. Late Oligocene.

Remarks. This form was observed only in Sample 516F-15-6, $80-82 \mathrm{~cm}$, where it is rare in abundance.

\section{Rocella semigelida n. sp. (Plate 2, Fig. 1-12)}

Description. Valves quasi-circular; surface covered by two, rarely three, loosely defined rings of large, subcircular to subelliptical holes that achieve their largest size about midway between the center and margin of the valve; a ring of somewhat smaller holes is situated near the margin. At the center of the valve is an enlarged hyaline part, which is perforated by a small pore and an adjacent labiate process. 
Diatom species

\begin{tabular}{|c|c|c|c|c|c|c|c|c|c|c|c|}
\hline 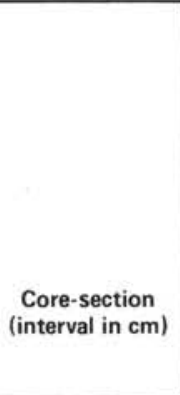 & 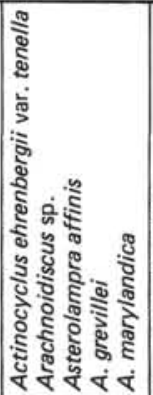 & 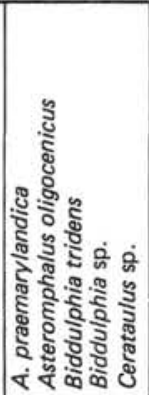 & 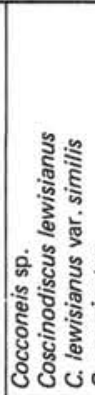 & 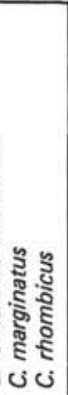 & 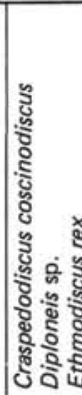 & 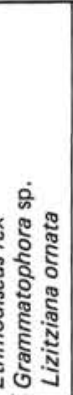 & 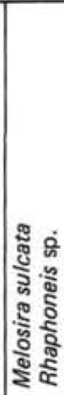 & 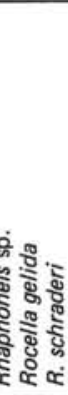 & 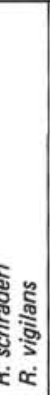 & 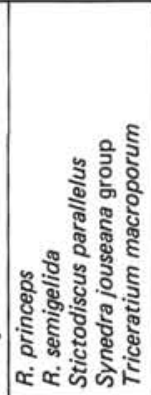 & 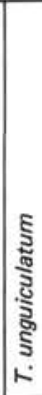 \\
\hline $\begin{array}{l}1-1,80-82 \\
1-2,80-82 \\
2-1,44-46 \\
2-2,96-98 \\
2-3,28-30\end{array}$ & & & & 4 & & & & & & 1 & \\
\hline $\begin{array}{l}2 \cdot 4,76-78 \\
2 \cdot 5,100-102 \\
2 \cdot 6,80-82 \\
3-1,87-89 \\
3-2,116-118\end{array}$ & & & & & & & & 1 & & 1 & \\
\hline $\begin{array}{l}3-3,84-86 \\
3-4,94-96 \\
3-5,80-82 \\
3-6,90-92 \\
4-1,100-102\end{array}$ & & & & & 1 & & & & & & \\
\hline $\begin{array}{l}4-2,48-50 \\
4 \cdot 3,84-86 \\
4 \cdot 4,24-26 \\
4 \cdot 5,79-81 \\
4 \cdot 6,140-142\end{array}$ & & & & BAR & REN & & & & & & \\
\hline $\begin{array}{l}5-1,66-68 \\
5-2,94-96 \\
5-3,120-122 \\
5 \cdot 4,84-86 \\
5 \cdot 5,80-82\end{array}$ & & & & & & & & & & & \\
\hline $\begin{array}{l}5-6,80-82 \\
6-1,86-88 \\
6-2,49-51 \\
7-1,80-82 \\
7-2,82-84\end{array}$ & 1 & 1 & 1 & $\begin{array}{l}1 \\
3 \\
6\end{array}$ & 12 & 1 & $\begin{array}{l}5 \\
7\end{array}$ & $\begin{array}{c}14 \\
28 \\
18 \\
6\end{array}$ & & $\begin{array}{l}1 \\
1 \\
1 \\
1\end{array}$ & \\
\hline $\begin{array}{l}7-3,80-82 \\
8-1,88-90 \\
8-2,34-36 \\
8-3,90-92 \\
8-4,64-66\end{array}$ & $\begin{array}{rr}162 & 27 \\
& 1\end{array}$ & 1 & $\begin{array}{r}217 \\
1\end{array}$ & 52 & $\begin{array}{r}42 \\
1 \\
41\end{array}$ & $\begin{array}{l}3 \\
1\end{array}$ & $\begin{array}{l}3 \\
3 \\
2 \\
2\end{array}$ & $\begin{array}{c}4 \\
147 \\
53 \\
28\end{array}$ & $\begin{array}{l}8 \\
5\end{array}$ & $\begin{array}{l}1 \\
6206 \\
1 \\
1 \\
22 \\
2\end{array}$ & \\
\hline $\begin{array}{l}8-5,92-94 \\
8-6,100-102 \\
9-1,80-82 \\
9-2,84-86 \\
9-3,56-58\end{array}$ & $\begin{array}{ll}1 & \\
& 1 \\
2 & 1 \\
1\end{array}$ & & & $3^{1}$ & 1 & 1 & $\begin{array}{l}7 \\
3 \\
1\end{array}$ & $\begin{array}{c}2 \\
170 \\
91 \\
23 \\
39\end{array}$ & $\begin{array}{l}4 \\
1\end{array}$ & $\begin{array}{c}121 \\
4 \\
1\end{array}$ & \\
\hline $\begin{array}{l}9-4,92-94 \\
10-1,90-92 \\
10-2,116-118 \\
10-3,100-102 \\
11-1,100-102\end{array}$ & $\begin{array}{l}1 \\
3 \\
1\end{array}$ & & 1 & $\begin{array}{l}3 \\
1\end{array}$ & 1 & $\begin{array}{l}1 \\
2\end{array}$ & $\begin{array}{l}1 \\
2\end{array}$ & $\begin{array}{c}28 \\
55 \\
8\end{array}$ & 1 & $\begin{array}{ccc}2 & 3 & 1 \\
3 & 2 & \\
1 & 10 & 1 \\
4 & \end{array}$ & \\
\hline $\begin{array}{l}11-2,120-122 \\
11-3,121-123 \\
11-4,39-41 \\
12-1,112-114 \\
13-1,90-92\end{array}$ & 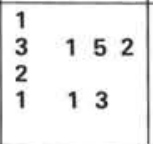 & $\begin{array}{cc} & 1 \\
2 & 19 \\
& 3 \\
3 & 5\end{array}$ & $\begin{array}{r}1 \\
16 \\
1\end{array}$ & $\begin{array}{ll}1^{4} \\
1 \\
6\end{array}$ & $\begin{array}{l}1 \\
1\end{array}$ & $\begin{array}{l}43 \\
2 \\
1\end{array}$ & $\begin{array}{l}1 \\
7 \\
2 \\
4 \\
3\end{array}$ & $\begin{array}{r}1 \\
1 \\
3 \\
3 \\
3\end{array}$ & \begin{tabular}{c|}
10 \\
164 \\
30 \\
32 \\
31
\end{tabular} & $\begin{array}{ll}2 & 5 \\
1 & C \\
2 & C \\
5 & C \\
1 & C\end{array}$ & \\
\hline $\begin{array}{l}13-2,84-86 \\
13-3,90-92 \\
15 \cdot 1,32-34 \\
15 \cdot 2,84-86 \\
15-3,130-132\end{array}$ & & & & 1 & 1 & & $\begin{array}{l}1 \\
6 \\
2 \\
2\end{array}$ & 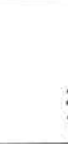 & $\begin{array}{l}2 \\
1\end{array}$ & 1 & \\
\hline $\begin{array}{l}15-4,80-82 \\
15-5,70-72 \\
15-6,80-82 \\
17-1,110-112 \\
17-2,94-96\end{array}$ & 1 & 312 & & $\begin{array}{l}1 \\
1\end{array}$ & 1 & & $\begin{array}{l}2 \\
1 \\
25 \\
1\end{array}$ & 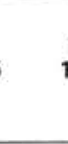 & $\begin{array}{c}1 \\
11\end{array}$ & $\begin{array}{r}1 \\
\text { C } 6\end{array}$ & 2 \\
\hline $18-1,74-76$ & & & & & & & & & & & \\
\hline
\end{tabular}

Figure 3. Occurrence of diatoms in samples from Hole 516F. Counts indicate the number of specimens observed in two traverses of $22 \times 22 \mathrm{~mm}$ cover slip at $\times 400 ; \mathrm{C}=11$ to 50 specimens observed in two traverses; blank = not present. 


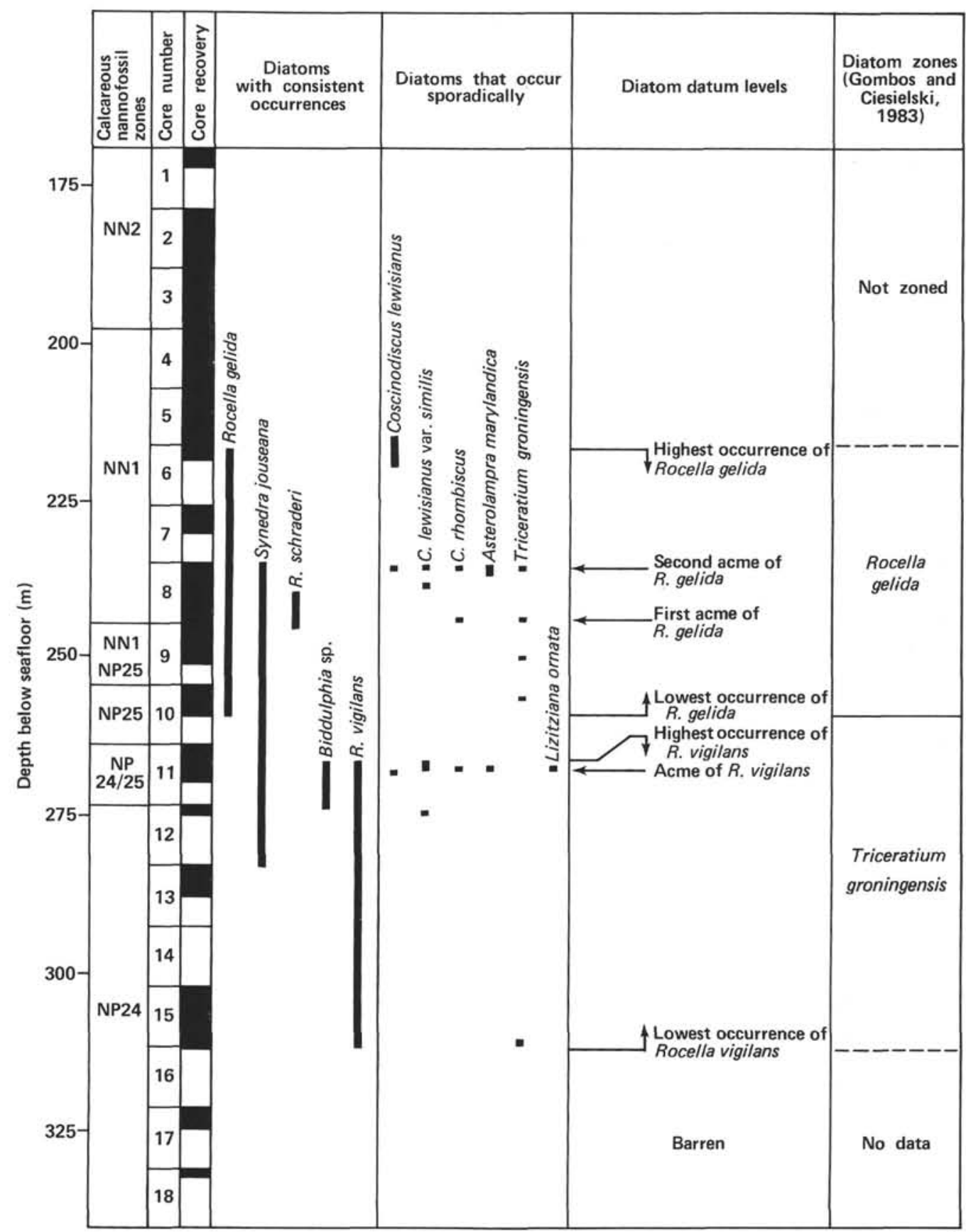

Figure 4. Lithology, calcareous microfossil ages and diatom zones, ages, and occurrence of selected diatom species in Hole 516F. In the "Core Recovery" column, black shows the amount of core recovered.

Mantle is steep and is constructed of a single band of large holes (see Plate 2, Fig. 7); in valve view, the mantle often appears as a dark band with intermittent darker, radial bands that correspond to the borders of the holes. Diameter of holotype is $54 \mu \mathrm{m}$; average diameter of 20 measured specimens $55 \mu \mathrm{m}$.

Holotype. Author's slide D29BJ3; holotype is circumscribed on the slide and is illustrated on Plate 2, Figure 5.

Repository. (CM 34391) Section of Invertebrate Fossils, Carnegie Museum of Natural History, 4400 Forbes Avenue, Pittsburgh, Pennsylvania 15213.

Type locality. DSDP Site $516\left(30^{\circ} 16.59^{\prime} \mathrm{S} ; 35^{\circ} 17.11^{\prime} \mathrm{W}\right)$ on the Rio Grande Rise in the South Atlantic Ocean.
Type stratum. DSDP Sample 516F-15-6, $80-82 \mathrm{~cm}$ (or 311.90 to $311.92 \mathrm{~m}$ below the sediment surface).

Age. Late Oligocene.

Remarks. This species was observed only in Sample 516F-15-6, 80$82 \mathrm{~cm}$, where it is common. This occurrence in Hole 516F is well below the lowest occurrence of Rocella gelida and is coincident with the lowest occurrence of $R$. vigilans. The stratigraphic range of this species could not be determined because of the poor preservation of diatoms in the hole. $R$. semigelida is similar to both $R$. vigilans and $R$. gelida. It differs from $R$. vigilans by the larger, nonuniform holes. It differs from $R$. gelida by the somewhat flatter nature of the valves, by the apparent lack of sculpturing on the struts between the holes (cf. 
Table 1. List of diatom species considered in this report.

Actinocyclus ehrenbergii Ralfs var. tenella (Brebisson) Hustedt, 1929 Asterolampra affinis Greville, 1862

A. grevillei (Wallich) Greville, 1860

A. marylandica Ehrenberg, 1844

A. praemarylandica Jousé, 1974

Asteromphalus oligocenicus Schrader and Fenner, 1976

Biddulphia tridens (Ehrenberg) Ehrenberg, 1840

Coscinodiscus lewisianus Greville, 1866

C. lewisianus Greville var. similis Rattray, 1890

C. marginatus Ehrenberg, 1841

C. praenitidus Fenner, 1976

C. rhombicus Castracane, 1886

Craspedodiscus coscinodiscus Ehrenberg, 1844

C. elegans Ehrenberg, 1844

Ethmodiscus rex Castracane degli Antelminelli, 1886

Hemiaulus caracteristicus Hajós, 1976

H. incisus Hajós, 1976

Lisitziana ornata Jousé, 1978

Melosira sulcata (Ehrenberg) Kutzing, 1844

Pyrgupyxis eocena Hendey, 1969

Pyxilla prolongata s.1. Burn, 1893

Rocella gelida (Mann) Bukry, 1978

$R$. princeps (Jousé) Fenner, in press

$R$. schraderi Bukry, 1978

$R$. vigilans (Schmidt) Fenner, in press

Stephanopyxis megapora Grunow, 1884

Stictodiscus parallelus (Ehrenberg) Grove and Sturt, 1887

Synedra jouseana Sheshukova-Poretzkaya, 1962

T. crenulatum Grove and Sturt, 1887

T. groningensis Reinhold, 1937

T. unguiculatum Greville, 1864

Trinacria excavata Heiberg, 1863

T. simulacrum Grove and Sturt, 1887

Hanna, 1930, fig. 2, 3, 7, 10; this report, Plate 1, Fig. 1-2), and by the single, marginal ring of somewhat smaller holes.

\section{REFERENCES}

Brun, J., 1890-1893. Notes sur quelques especes nouvelles. In Tempere, J. (Ed.), Le Diatomiste, (Vol. 1): Paris (M. J. Tempere), 173-177.

Bukry, D., 1978. Cenozoic silicoflagellate and coccolith stratigraphy, northwestern Atlantic Ocean, DSDP Leg 43. In Benson, W. E., Sheridan, R. E., et al., Init. Repts. DSDP, 44: Washington (U.S. Govt. Printing Office), 775-805.

Castracane degli Antelminelli, F., 1886. The Voyage of H.M.S. Challenger. Report on the Diatomaceae. Botany 2 (I-III), 1: Edinburgh (Ballantyne, Hanson, and Co.) (reprinted 1966).

Ehrenberg, C. C., 1840. Über ausgezeichnete jetzt noch lebende peruanische und mexikanische Meeres-Infusorien, welche mit zur Erläuterung rätselhafter fossiler Formen der Kreidebildung dienen. Ber. K. Preuss. Akad. Wiss. Berlin, pp. 157-162.

1841. Verbreitung und Einfluss des mikroskopischen Lebens in Süd- und Nord-America. Abh. K. Akad. Wiss. Berlin, Pt. $1: 291-445$.

1844. Mitteilung über zwei neue Lager von Gebirgsmassen aus Infusorien als Meeres-Absatz in Nord-America und eine Vergleichung derselben mit den organischen Kreidegebilden in Europa und Afrika. Ber. K. Preuss Akad. Wiss. Berlin, pp. 57-97.

Fenner, J., 1978. Cenozoic diatom biostratigraphy of the equatorial and southern Atlantic Ocean. In Supko, P. R., Perch-Nielsen, K., et al., Init. Repts. DSDP, Suppl. to Vols. 38, 39, 40, and 41: Washington (U.S. Govt. Printing Office), 491-623.

Gombos, A. M., Jr., 1977. Paleogene and Neogene diatoms from the Falkland Plateau and Malvinas Outer Basin: Leg 36, Deep Sea Drilling Project. In Barker, P. F., Dalziel, I. W. D., et al., Init. Repts. DSDP, 36: Washington (U.S. Govt. Printing Office), 575-687.

Gombos, A. M., Jr., and Ciesielski, P. F., 1983. Late Eocene to early Miocene diatoms from the southwest Atlantic Ocean. In Ludwig,
W. J., Krasheninnikov, V. A., et al., Init. Repts. DSDP, 71: Washington (U.S. Govt. Printing Office), 583-634.

Greville, R. K., 1860. A monograph of the genus Asterolampra including Asteromphalus and Spatangidium. Trans. Microsc. Soc. London, N.S., 8:102-124. 1861-1866. Descriptions of new and rare diatoms. Ser. IXX. Trans. Microsc. Soc. London, N.S., 9-14; Q. J. Microsc. Sci., N.S., 2-3, 1862. On the Asterolamprae of the Barbados deposit. Trans. Microsc. Soc. London, 10:41-55.

Grove, E., and Sturt, G., 1886-1887. On a fossil marine diatomaceous deposit from Oamaru, Otago, New Zealand. J. Quekett Microsc. Club, Ser. II, 2(16):321-330; 3(17)7-12; 3(18):63-78; 3(19):131-148.

Grunow, A., 1884. Diatomeen von Franz Josef-Land. Denkschr. $K$. Akad. Wiss. Wien, 48:53-112.

Hajós, M., 1976. Upper Eocene and lower Oligocene Diatomaceae, Archaeomonadaceae, and Silicoflagellatae in southwestern Pacific sediments, DSDP Leg 29. In Hollister, C. D., Craddock, C., et al., Init. Repts. DSDP, 35: Washington (U.S. Govt. Printing Office), 817-883.

Hanna, G. D., 1930. A new genus of Silicoflagellata from the Miocene of lower California. J. Paleontol., 4:415-416.

Heiberg, P. A. C., 1863. Conspectus Criticus Diatomacearum Danicarum: Kritisk Oversigt over De Danske Diatomeer: Copenhagen (Wilhelm Priors Forlag), pp. 1-135.

Hendey, N. I., 1969. Pyrgupyxis, a new genus of diatoms from a South Atlantic Eocene core. Occas. Pap. Calif. Acad. Sci., No. 72:1-6.

Hendey, N. I., and Wiseman, D. H., 1953. The significance and diatom content of a deep-sea floor sample from the neighborhood of the greatest oceanic depth. Deep-Sea Res., 1:47-59.

Hustedt, F., 1929. Die Kieselalgen Deutschlands, Osterreichs und der Schweiz mit Beruchsichtigung der übrigen Länder Europas zowie der angrenzenden Meeresgebiete. Rabenhorst, L., (Ed.) Kryptogamenflora von Deutschland, Osterreich und der Schweiz (Vol. 7, Pt. 1): Leipzig (Akademische Verlagsgesellschaft), 465-608.

Jousé, A. P., 1974. Diatoms in the Oligocene-Miocene biostratigraphic zones of the tropical areas of the Pacific Ocean. Nova Hedwigia, 45:333-357.

1978. New fossil genus of diatoms (Lisitzina [Bacillariophyta]). Marskaya mikropaleontologiya Moscow, pp. 47-48. 1979. Diatom biostratigraphic zones of the Eocene. Nova Hedwigia, 64:427-440.

Kutzing, F. T., 1844. Die Kieselschaligen Bacillarien oder Diatomeen: Nordhausen (Ferd. Forstemann).

Rattray, J., 1890. A revision of the genus Actinocyclus Ehrb. J. Quekett Micro. Club., Ser. 2, 4:137-212.

Reinhold, T., 1937. Fossil diatoms of the Neogene of Java and their zonal distribution. Verhandelingen van het Geologisch-Mijnbouwkundig Genotschap voor Nederland en Kolonien. Geol. Ser., 12: $1-132$.

Schmidt, A., 1874-1959. Atlas der Diatomaceenkunde, begun by A. Schmidt, continued by Schmidt M., Fricke F., Müller O., Heiden H., and Hustedt F., Leipzig, Berlin (O. R. Reisland).

Schrader, H., and Fenner, J., 1976. Norwegian Sea Cenozoic diatom biostratigraphy and taxonomy: Part 1 , Norwegian Sea Cenozoic diatom biostratigraphy. In Talwani, M., Udintsev, G., et al., Init. Repts. DSDP, 38: Washington (U.S. Govt. Printing Office), 921-962.

Sheshukova-Poretskaya, V. S., 1962. Novie i redkie Bacillariophyta iz diatomovoi sviti Sakhalina. Uch. Zap. lgu. Ser. Biol. Nauk, Leningrad Univ.), 49:203-211.

VanLandingham, S., 1967-1979. Catalogue of the fossil and recent genera and species of diatoms and their synonyms. Part I (1967) Acanthoceras through Bacillaria; Part II (1968) Bacteriastrum through Coscinodiscus; Part III (1969) Coscinosphaena through Fibula; Part IV (1971) Fragilaria through Naunema; Part V (1975) Navicula; Part VI (1978a) Neidium through Rhoicosigma; Part VII (1978b) Rhoicosphenia through Zygoceros; Part VIII (1979) Supplement. Lehre (Cramer).

Date of Initial Receipt: March 2, 1982 



11
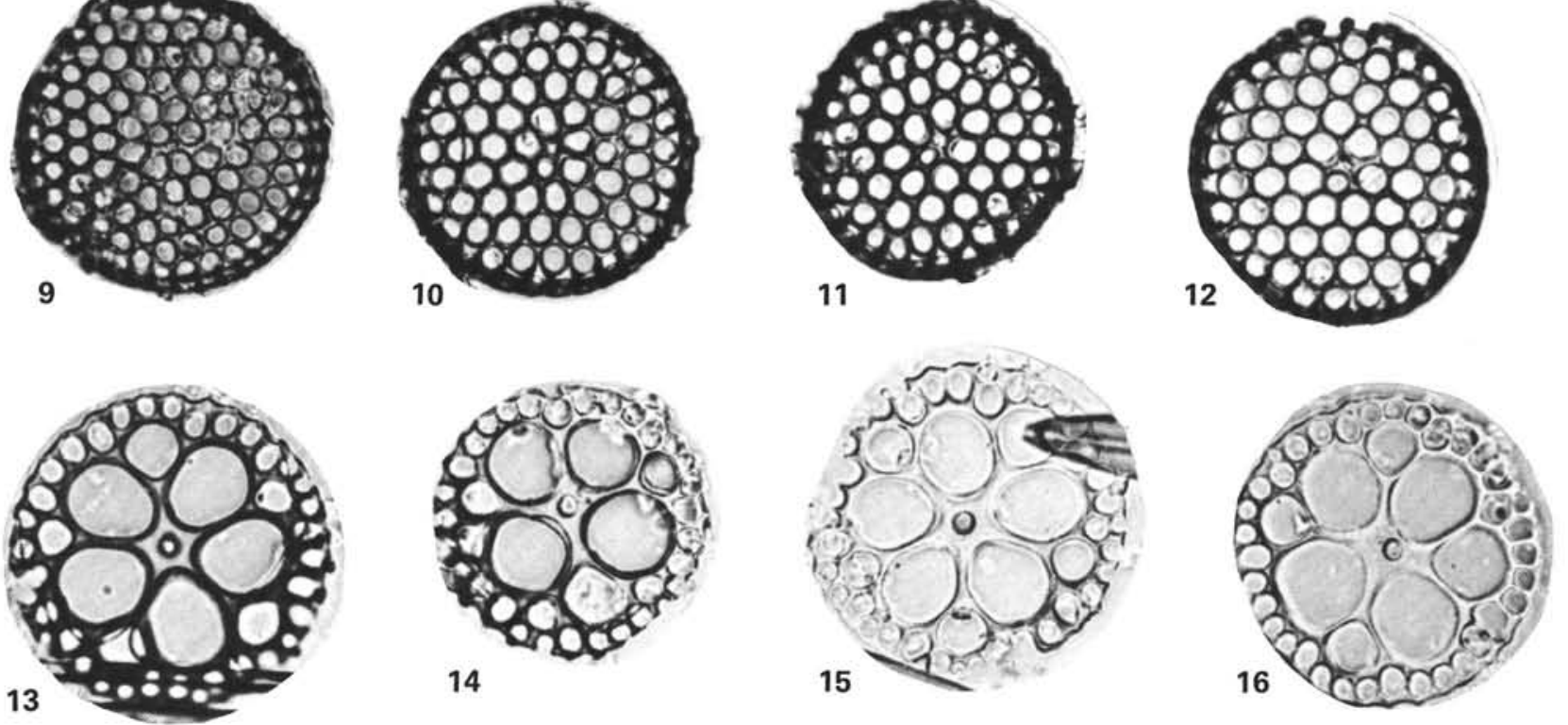

Plate 1. (All specimens magnified $\times 500$.) 1-2. Rocella gelida (Mann) Bukry, Sample $516 \mathrm{~F}-8-1,88-90 \mathrm{~cm}$. 3-6. $R$. gelida (Mann) Bukry, Sample 516F-11-1, 100-102 cm. 7-12. R. vigilans (Schmidt) Fenner, (7-8) Sample 516F-11-3, 121-123 cm, (9) Sample 516F-15-6, 80-82 cm, (10) Sample 516F-11-3, 121-123 cm, (11-12). Sample 516F-11-2, 120-122 cm. 13-16. $R$. schraderi Bukry, Sample 516F-8-3, 90-92 cm. 

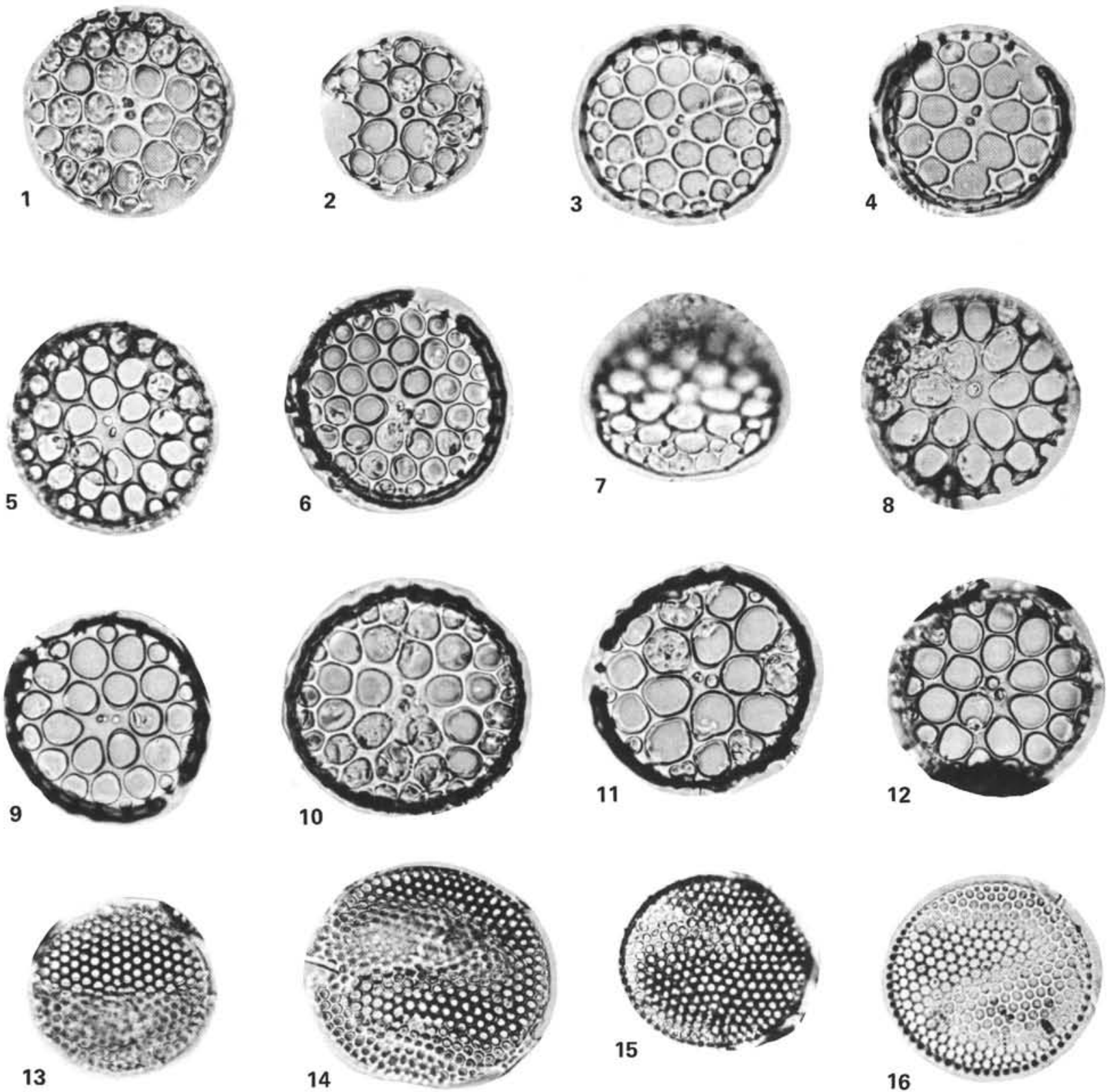

Plate 2. (All specimens magnified $\times 500$.) 1-12. Rocella semigelida $\mathrm{n}$. sp., Sample $516 \mathrm{~F}-15-6,80-82 \mathrm{~cm}$, (5) Holotype. 13-16. $R$. princeps $($ Jouse) Fenner, Sample 516F-12-1, 112-114 cm. 

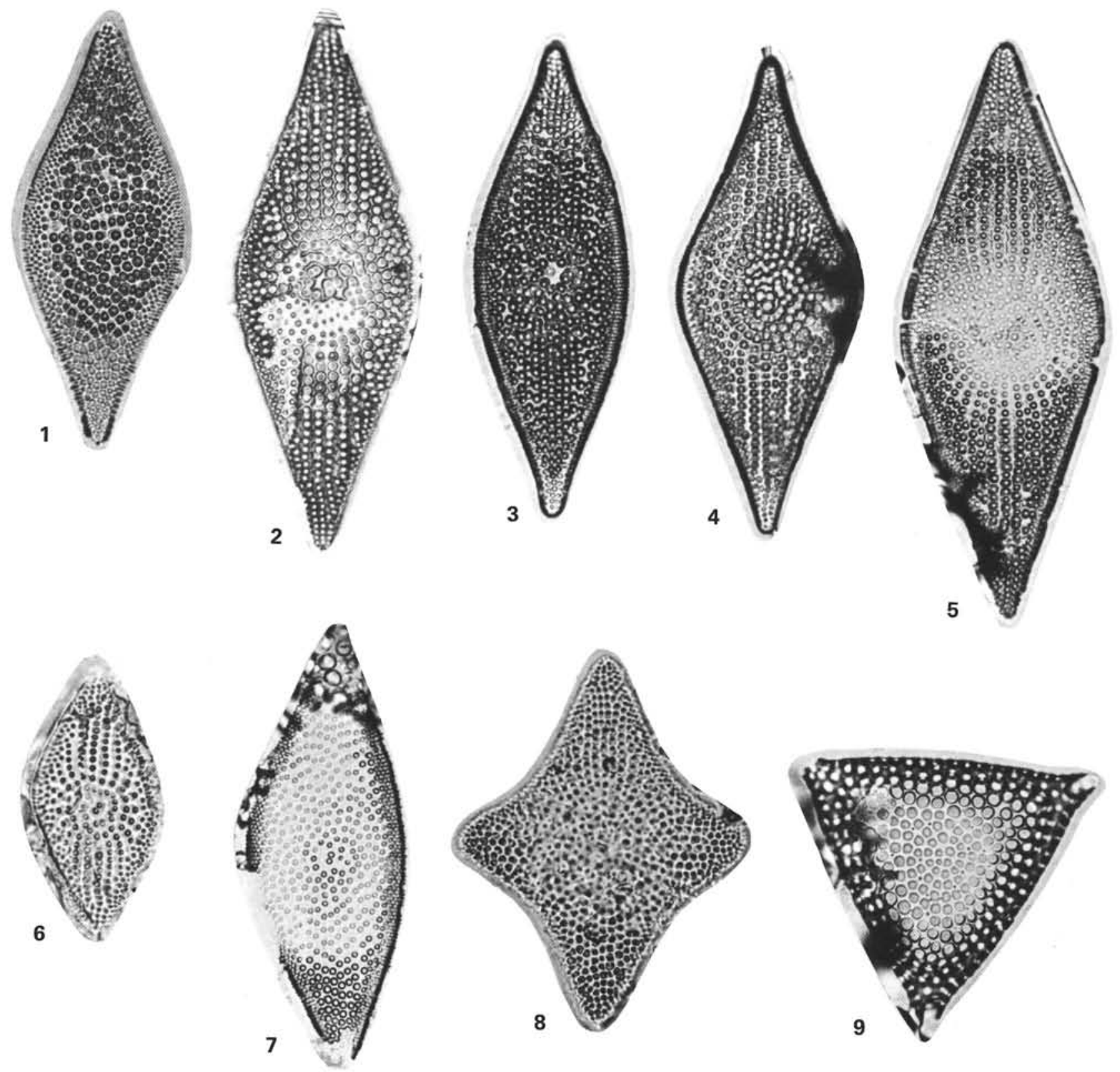

Plate 3. (All specimens magnified $\times 500$.) 1. Coscinodiscus rhombicus Castracane, Sample $516 \mathrm{~F}-8-1,88-90 \mathrm{~cm}$. 2-5. C. lewisianus Greville var. similis Rattray, Sample $516 \mathrm{~F}-8-1,88-90 \mathrm{~cm}$. 6. C. lewisianus Greville var. similis Rattray s.s., Sample $516 \mathrm{~F}-11-1,100-102 \mathrm{~cm}$. 7. C. cf. C. rhombicus Castracane, Sample 516F-8-1, 88-90 cm. 8. C. lewisianus Greville f. concavus n.f. (holotype), Sample 516F-15-6, 80-82 cm. 9. Triceratium groningensis Reinhold, Sample 516F-8-1, 88-90 cm. 

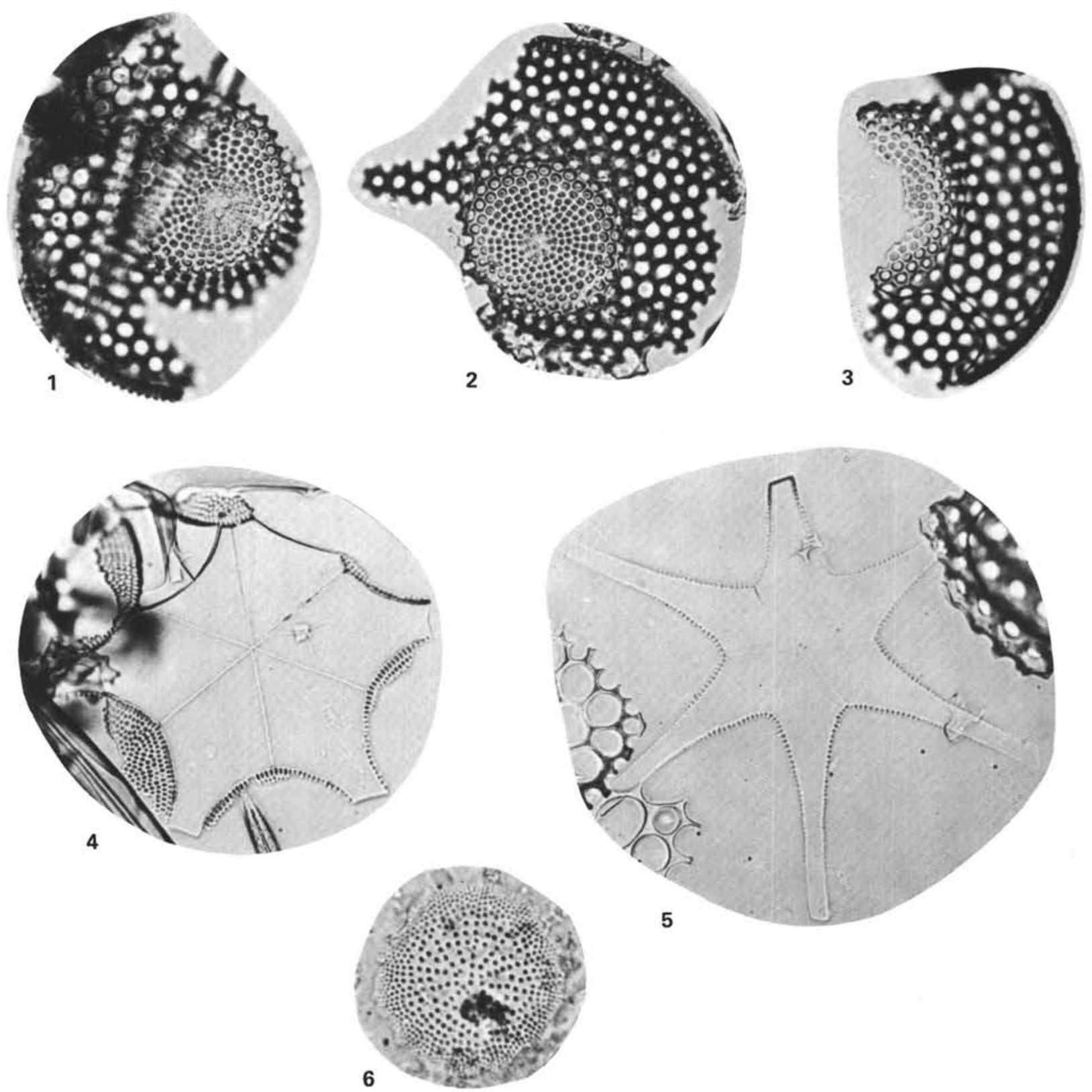

Plate 4. (All specimens magnified $\times 500$.) 1-3. Craspedodiscus coscinodiscus Ehrenberg. (1) Sample 516F-15-6, 80-82 cm. (2) Sample 516F-9-1, $80-82 \mathrm{~cm}$. (3) Sample 516F-15-6, 80-82 cm. 4. Asterolampra marylandica Ehrenberg, Sample $516 \mathrm{~F}-8-1,88-90 \mathrm{~cm}$. 5. A. praemarylandica Jousé, Sample 516F-8-1, 88-90 tm. 6. Actinocyclus ehrenbergii Ralfs var. tenella (Brebisson) Hustedt, Sample 516F-11-1, 100-102 cm. 
A. M. GOMBOS, JR.

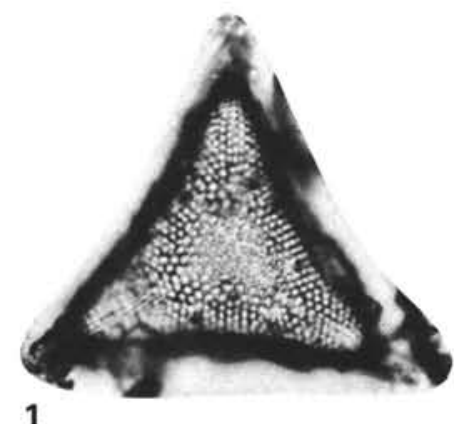

1

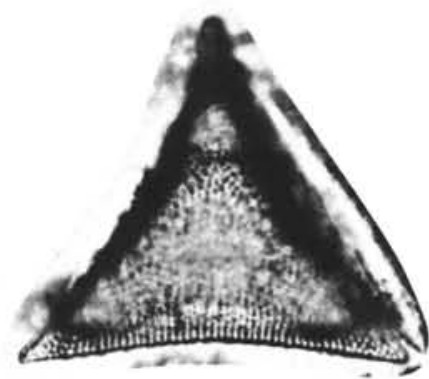

4

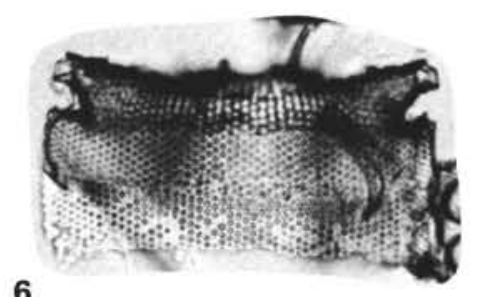

6

Plate 5. (All specimens magnified $\times 500$.) 1-7. Biddulphia sp., Sample $516 \mathrm{~F}-11-3,121-123 \mathrm{~cm}$. 